\title{
Organic condensation: a vital link connecting aerosol formation to cloud condensation nuclei $(\mathrm{CCN})$ concentrations
}

\author{
I. Riipinen ${ }^{1,2}$, J. R. Pierce ${ }^{3}$, T. Yli-Juuti ${ }^{2}$, T. Nieminen ${ }^{2}$, S. Häkkinen ${ }^{2}$, M. Ehn ${ }^{2}$, H. Junninen ${ }^{2}$, K. Lehtipalo ${ }^{2}$, \\ T. Petäjä ${ }^{2}$, J. Slowik ${ }^{4}{ }^{*}$, R. Chang ${ }^{4}$, N. C. Shantz ${ }^{5}$, J. Abbatt ${ }^{4}$, W. R. Leaitch ${ }^{5}$, V.-M. Kerminen ${ }^{2,6}$, D. R. Worsnop ${ }^{2,7}$, \\ S. N. Pandis ${ }^{1,8}$, N. M. Donahue ${ }^{1}$, and M. Kulmala ${ }^{2}$ \\ ${ }^{1}$ Center for Atmospheric Particle Studies (CAPS), Carnegie Mellon University, 15213, Pittsburgh, PA, USA \\ ${ }^{2}$ Department of Physics, University of Helsinki, 00014, Helsinki, Finland \\ ${ }^{3}$ Department of Physics and Atmospheric Science, Dalhousie University, B3H 3J5, Halifax, NS, Canada \\ ${ }^{4}$ Department of Chemistry, University of Toronto, M5S 3H6, Toronto, ON, Canada \\ ${ }^{5}$ Science and Technology Branch, Environment Canada, M3H 5T4, Toronto, ON, Canada \\ ${ }^{6}$ Finnish Meteorological Institute, 00880, Helsinki, Finland \\ ${ }^{7}$ Aerodyne Research Inc., 01821, Billerica, MA, USA \\ ${ }^{8}$ Institute of Chemical Engineering and High Temperature Processes (ICE-HT) Foundation for Research \& Technology, \\ Hellas (FORTH), 26504, Patra, Greece \\ * now at: Paul Scherrer Institute, 5232 Villigen PSI, Switzerland
}

Received: 10 December 2010 - Published in Atmos. Chem. Phys. Discuss.: 6 January 2011

Revised: 12 April 2011 - Accepted: 13 April 2011 - Published: 27 April 2011

\begin{abstract}
Atmospheric aerosol particles influence global climate as well as impair air quality through their effects on atmospheric visibility and human health. Ultrafine $(<100 \mathrm{~nm})$ particles often dominate aerosol numbers, and nucleation of atmospheric vapors is an important source of these particles. To have climatic relevance, however, the freshly nucleated particles need to grow in size. We combine observations from two continental sites (Egbert, Canada and Hyytiälä, Finland) to show that condensation of organic vapors is a crucial factor governing the lifetimes and climatic importance of the smallest atmospheric particles. We model the observed ultrafine aerosol growth with a simplified scheme approximating the condensing species as a mixture of effectively non-volatile and semi-volatile species, demonstrate that state-of-the-art organic gas-particle partitioning models fail to reproduce the observations, and propose a modeling approach that is consistent with the measurements. We find that roughly half of the mass of the condensing mass needs to be distributed proportional to the aerosol surface area (thus implying that the condensation is governed by gas-phase concentration rather than the equilibrium vapour pressure) to explain the observed aerosol growth. We demonstrate the
\end{abstract}

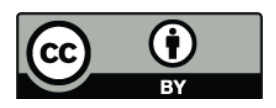

Correspondence to: I. Riipinen (ilona.riipinen@ @elsinki.fi) large sensitivity of predicted number concentrations of cloud condensation nuclei $(\mathrm{CCN})$ to these interactions between organic vapors and the smallest atmospheric nanoparticles highlighting the need for representing this process in global climate models.

\section{Introduction}

Aerosol particles impact the climate by scattering and absorbing solar radiation, as well as acting as cloud condensation nuclei $(\mathrm{CCN})$ and regulating the properties of clouds (Rosenfeld et al., 2008; Clement et al., 2009). Aerosols are also among the main pollutants deteriorating air quality (Nel, 2005). According to the Intergovernmental Panel on Climate Change, aerosols have been the most important atmospheric cooling component in the industrial period, but the predictions of aerosol impacts are the largest individual source of uncertainty in climate models (IPCC, 2007). To constrain the effects of aerosols on climate and air quality, the processes governing their concentrations need to be represented accurately in large-scale models.

A significant fraction (20-90\%) of sub-micrometer atmospheric particulate matter consists of organic compounds (Jimenez et al., 2009). The sources, sinks and chemistry of organic aerosol (OA) are still uncertain because of the large

Published by Copernicus Publications on behalf of the European Geosciences Union. 


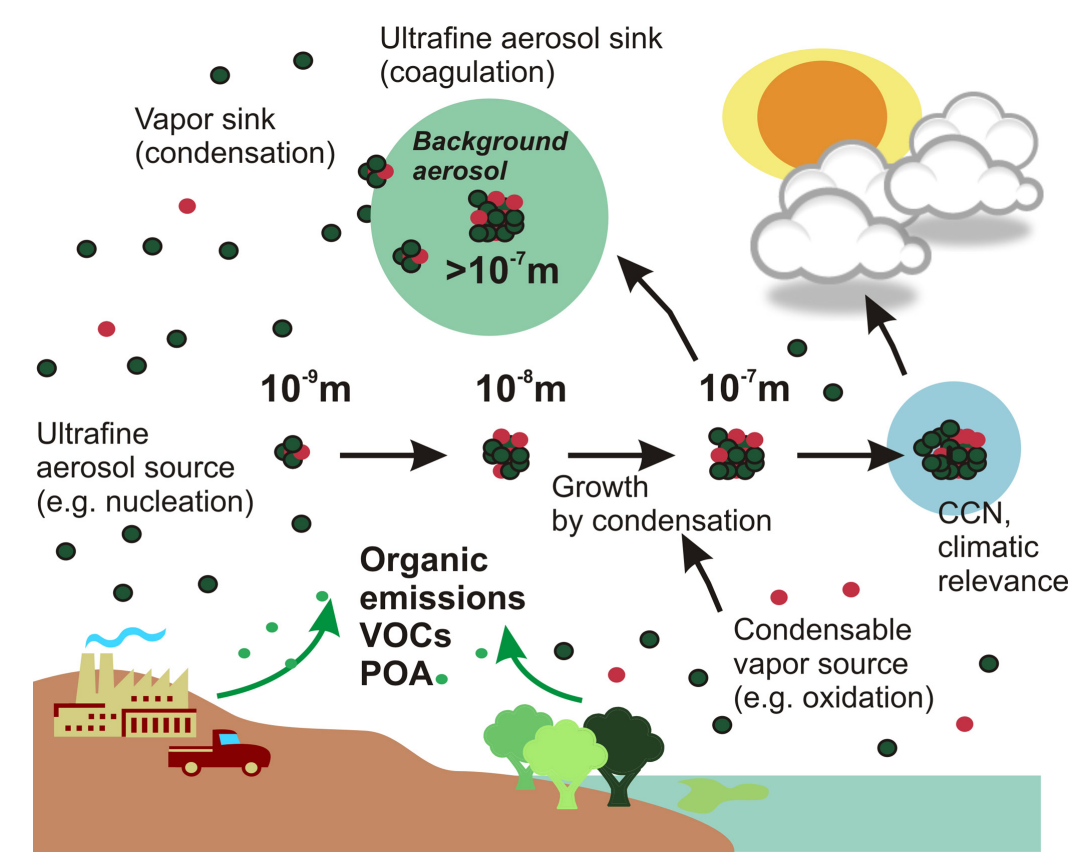

Fig. 1. Organic emissions and the dynamic processes governing the climatic importance of ultrafine aerosol. Condensable vapors are produced upon oxidation of volatile organic compounds (VOCs) and can (1) nucleate to form new small particles; (2) grow freshly formed particles to larger sizes and increase their probability to serve as CCN; (3) condense on the background aerosol (>100 nm) and enhance the loss of ultrafine particles. Primary organic aerosol (POA) contributes to the large end of the aerosol size distribution, enhancing the scavenging of the ultrafine particles.

number of different atmospheric organic molecules (Goldstein and Galbally, 2007). Accurately representing OA in atmospheric models is one of the key requirements for understanding the climate effects of aerosols. Consequently, OA has been the subject of numerous studies during the last decade (Hallquist et al., 2009). Significant improvements in the predictions of OA mass have been achieved (Murphy and Pandis, 2009), one of the major developments being the representation of $\mathrm{OA}$ as a mixture of semi-volatile components that move between condensed and gas phases (Odum et al., 1996; Donahue et al., 2006). It is not well known, however, how organics affect the size distribution of ultrafine particles - which usually dominate atmospheric aerosol number concentrations. This information is crucial in determining the effect of organics on $\mathrm{CCN}$ numbers: the size of an aerosol particle is among the main factors governing its climatic effect (Dusek et al., 2006), as only particles with diameters larger than about 30 to $100 \mathrm{~nm}$ can act as CCN. If a significant amount of the organic mass condenses on ultrafine aerosol, more of these particles reach climatically relevant sizes; increasing global CCN concentrations. If organics condense preferentially on $D_{\mathrm{p}}>100 \mathrm{~nm}$ particles, they enhance the scavenging of ultrafine particles, reducing $\mathrm{CCN}$ (see Fig. 1 for a schematic).

Nucleation occurs in various environments around the world (Kulmala et al., 2004), and is an important source of aerosol. Sulfuric acid is a key component in particle formation processes (Sipilä et al., 2010), and nucleation rates can be predicted relatively well based on ambient sulfuric acid concentrations (Spracklen et al., 2010). The lifetimes of these particles, however, depend on the competition between their condensational growth and coagulational scavenging (Kerminen and Kulmala, 2002). Thus both nucleation rates and condensational growth of ultrafine particles must be accurately represented in large-scale atmospheric models. The contribution of organics to the total condensational flux onto ultrafine particles must be quantified to achieve this goal. The same material that grows the freshly-nucleated particles also naturally condenses on the primary ultrafine particles.

The driving force for condensation/evaporation to/from an aerosol particle is the difference between the ambient vapor partial pressure and the equilibrium vapor pressure over the particle surface. The dynamics of the resulting mass transfer are governed by the laws of diffusion and gas kinetic theory. Laboratory observations of aerosol growth can be reproduced accurately with mass and heat transfer models - if the properties, particularly the saturation pressures, of the vapors are known (Vesala et al., 1997). Unfortunately only a fraction of atmospheric organic molecules have been identified and information on their thermodynamic properties is scarce.

To model organic condensation, most large-scale models either (1) apply partitioning theory (Pankow, 1994), assuming that organic vapors equilibrate instantaneously with the aerosol by absorption into organic mass; or, (2) assume that 
$\mathrm{OA}$ is non-volatile and that the vapors condense kinetically onto the aerosol surface area (Spracklen et al., 2010). Partitioning theory accounts for different volatilities of OA, treating their mixing thermodynamics as well as changes in organic volatility due to photochemical aging. If instantaneous equilibration is assumed, however, the size-dependent kinetics of condensation is neglected. Consequently the organics are predicted to be absorbed onto the large end of the particle size spectrum. Treating the organic vapors as completely non-volatile, on the other hand, only accounts for the kinetics, neglecting their thermodynamic properties. To our knowledge, there is currently no large-scale modeling approach that accounts for both (1) the condensation and reevaporation of organics and (2) the size-dependent kinetics of the mass transfer.

We combine observations from Hyytiälä, Finland, and Egbert, ON, Canada with an aerosol dynamic model to quantify the contribution of organics to ultrafine particle growth. We develop a modeling approach that approximates the effects of condensation kinetics and bulk equilibration for atmospheric organics, and reproduces both the total OA mass and the observed ultrafine particle growth. We use these results in global chemical transport model GEOS-Chem to demonstrate the importance of capturing the organic contribution to ultrafine particle growth for global aerosol number and $\mathrm{CCN}$ predictions.

\section{Field experiments}

\subsection{Measurements at Egbert, ON, Canada}

The Egbert 2007 study took place at Environment Canada's Centre for Atmospheric Research Experiments $\left(44^{\circ} 23^{\prime} \mathrm{N}\right.$, $79^{\circ} 78^{\prime} \mathrm{W}, 251 \mathrm{~m}$ a.s.l.) from 14 May to 15 June 2007. This semi-rural site at Egbert, Ontario is approximately $70 \mathrm{~km}$ north of Toronto (population $\sim 5$ million in the metropolitan area) and measurements made at this site are used by Environment Canada to represent background continental air in various monitoring networks. The air at this site is influenced by biogenic emissions from mixed forests when it originates from the north as well as anthropogenic emissions from the industrialised parts of southern Ontario and the United States when it originates from the south. The two days of data used in this study represent air transported from the north. Further information about this study can be found in Slowik et al. (2010).

\subsubsection{Aerosol number size distribution measurements at Egbert}

At Egbert, the ambient aerosol number size distribution was measured with commercial Scanning Mobility Particle Sizer (SMPS) system. Two SMPS's were used in this study: a nano-SMPS (TSI, 3080, 3085, 3025A) measured particle size distributions from $3-60 \mathrm{~nm}$, and a standard SMPS
(TSI 3071, 3081, 3010) measured size distributions from 10 $420 \mathrm{~nm}$. The sample flows of the nano- and standard systems were 1.5 and $11 \mathrm{~min}^{-1}$, respectively, while the sheath flows were 15 and $61 \mathrm{~min}^{-1}$, respectively. Both of these systems sampled approximately $5.5 \mathrm{~m}$ above ground from an intake manifold consisting of a PVC pipe lined with aluminium tape to reduce electrostatic deposition. The SMPS's sampled from the centre axis of this pipe and the particles had a total residence time of approximately $1 \mathrm{~min}$.

\subsubsection{Aerosol particle chemical composition measurements at Egbert using the Aerosol Mass Spectrometer (AMS)}

A time-of-flight aerosol mass spectrometer (C-ToF-AMS, Aerodyne Research, Inc., Billerica, MA, USA) was deployed at the Egbert site from 14 May to 15 June 2007. The AMS yields size-resolved mass spectra of the non-refractory submicron particles, where non-refractory refers to the component that is vaporizable at $\sim 600^{\circ} \mathrm{C}$ and $10^{-7}$ torr. Detailed descriptions of AMS operating principles are found elsewhere (Drewnik et al., 2006; Canagaratna et al., 2007), while operation of the AMS in the present study is discussed by Slowik et al. (2010). Briefly, particles are sampled through a $100 \mu \mathrm{m}$ critical orifice and focused into a narrow beam by an aerodynamic lens. Particles impact on a resistively heated surface $\left(600^{\circ} \mathrm{C}\right)$, are ionized by electron impact $(70 \mathrm{eV})$ and detected by time-of-flight mass spectrometry. Quantitative AMS measurements of mass concentrations are complicated by uncertainties in instrument collection efficiency, primarily caused by particle bounce off the vaporizer surface. At the Egbert site, an optical scattering module was used to obtain a light scattering pulse for every particle impacting the vaporizer having a geometric diameter greater than $\sim 215 \mathrm{~nm}$ (Cross et al., 2007) with these pulses used to trigger the saving of single particle mass spectra (Cross et al., 2009). The bounce collection efficiency can thus be calculated as the fraction of optical pulses having a correlated non-zero mass spectrum. A value of 0.6 was obtained at Egbert and assumed to hold across the entire size range.

\subsection{Measurements at the SMEAR II station in Hyytiälä, Finland}

The SMEAR II (Station for Measuring Forest EcosystemAtmosphere Relations) is located in a rather homogenous Scots pine (Pinus sylvestris L.) stand on flat terrain at Hyytiälä Forestry Field Station of the University of Helsinki $\left(61^{\circ} 51^{\prime} \mathrm{N}, 24^{\circ} 17^{\prime} \mathrm{E}, 181 \mathrm{~m}\right.$ a.s.l.). The biggest city near the SMEAR II is Tampere wchich has about 200000 inhabitants and is located about $60 \mathrm{~km}$ from the measurement site. Hari and Kulmala (2005) have described the station and its operation in detail. 


\subsubsection{Aerosol number size distribution measurements in Hyytiälä}

The neutral and charged aerosol particle size distributions used in this study have been measured in Hyytiälä using three different instruments: the Differential Mobility Particle Sizer (DMPS), the Balanced Scanning Mobility Analyzer (BSMA) and the Air Ion Spectrometer (AIS).

Continuous particle size distribution measurements in the 3-1000 nm sub-micron size range have been carried out with a Differential Mobility Particle Sizer (DMPS) system since January 1996 at the SMEAR II. The setup in Hyytiälä is a twin-DMPS, consisting of two separate DMPS systems: the first DMPS measures particles starting from $3 \mathrm{~nm}$ (applying a TSI 3025 Condensation Particle Counter, CPC), and the second from $10 \mathrm{~nm}$ (with a TSI 3010 CPC). Currently, the aerosol sample is collected from $8 \mathrm{~m}$ above ground level through a 8.5-m-long tube with an inner diameter of $10 \mathrm{~cm}$ and a flow velocity of $2361 \mathrm{~min}^{-1}$. The sample is conducted to the DMPS system from the center of this tube through a $35-\mathrm{cm}$-long secondary tube with $6 \mathrm{~mm}$ inner diameter. The sample flows further in the two Differential Mobility Analyzers (DMAs) are $11 \mathrm{~min}^{-1}$ and $41 \mathrm{~min}^{-1}$. For a detailed description of the DMPS setup applied in Hyytiälä, we direct the reader to Aalto et al. (2001).

The BSMA (Tammet, 2006) is an instrument capable of measuring mobility distributions of small air ions and naturally charged nanoparticles (intermediate ions) of both negative and positive polarity. The mobility range of the BSMA is 3.2 to $0.032 \mathrm{~cm}^{2} \mathrm{~V}^{-1} \mathrm{~s}^{-1}$, which corresponds to a mobility diameter range of 0.8 to $7.6 \mathrm{~nm}$ (see Ehn et al., 2011). The BSMA consists of two plain aspiration condensers, one for each polarity, and a common electrical amplifier connected to a balanced bridge circuit. Size segregation is obtained by varying the electric field via a discharge of a capacitor through the repelling electrode and monitoring the electrometer current in the balanced bridge circuit. In a normal measurement cycle the BSMA measures the mobility distributions of negative and positive ions, and the offset in an alternating manner. The data is averaged over $10 \mathrm{~min}$. A more detailed description of the instrument can be found in a paper by Tammet (2006) and examples of its atmospheric applications in a study by Hirsikko et al. (2007). The BSMA has been running continuously in Hyytiälä since 2003.

The AIS (Mirme et al., 2007) (Airel Ltd., Estonia) measures mobility distributions of both negative and positive air ions in the range from 3.16 to $0.00133 \mathrm{~cm}^{2} \mathrm{~V}^{-1} \mathrm{~s}^{-1}$. This corresponds to a diameter range of approximately 0.8 to $40 \mathrm{~nm}$. In essence, the AIS consists of two cylindrical Differential Mobility Analyzers (DMAs) equipped with insulated electrometer rings. Sampled ions are collected on the electrometer rings in 21 electrical mobility fractions simultaneously for both polarities. The AIS has been running continuously in Hyytiälä since 2003.

\subsubsection{Aerosol chemical characterization in Hyytiälä using the AMS and the V-DMPS systems}

The C-TOF Aerosol Mass Spectrometer (Drewnick et al., 2005) was deployed in Hyytiälä during the EUCAARI (European integrated project for Cloud-Aerosol-Air QualityInteractions, Kulmala et al., 2009) campaign between 7 April and 7 May 2007. The collection efficiency was determined to be 0.4 based on a comparison with concurrent DMPS measurements.

A volatility-DMPS (V-DMPS) was running in parallel with the basic DMPS in Hyytiälä in March and April 2007. The two instruments had the same size range $(3-1000 \mathrm{~nm})$ and time resolution $(10 \mathrm{~min})$, and took the sample air through a common inlet. The V-DMPS comprised of a heating tube and a twin-DMPS. The heating tube was an approximately $0.5 \mathrm{~m}$ long stainless steel tubing (o.d. $10 \mathrm{~mm}$ ) heated to $280^{\circ} \mathrm{C}$. The flow rate through the tube was $51 \mathrm{~min}^{-1}$, which gave the particles a residence time of approximately $0.5 \mathrm{~s}$ in the heated section. The data was corrected according to experimentally determined particle losses in the tube due to diffusion and thermophoresis (Ehn et al., 2007). After heating, the aerosol was neutralized using a $\mathrm{Ni}^{63}$ beta source. The first DMPS was optimized for particles between 3-40 nm and the second for particles between $15-1000 \mathrm{~nm}$. The size classification was done with Hauke type DMAs and the particle counting with butanol CPCs (TSI 3025 and 3010).

\subsubsection{Gas phase sulfuric acid concentration measurements and proxy calculations in Hyytiälä}

Gas phase sulfuric acid concentrations were measured with a Chemical Ionization Mass Spectrometer CIMS. The sulfuric acid measurements were part of the EUCAARI project between 24 March and 28 June 2007. Further details are given in Petäjä et al. (2009).

To extend the measured sulfuric acid data set for the full period of years 2003-2007, we calculated proxy concentrations for sulfuric acid. This proxy concentration is calculated as the ratio between the source and sink terms:

$\left[\mathrm{H}_{2} \mathrm{SO}_{4}\right]_{\text {proxy }}=k \cdot \frac{\left[\mathrm{SO}_{2}\right] \cdot \mathrm{GlobRad}}{\mathrm{CS}}$

Here the source term is approximated by the product of $\mathrm{SO}_{2}$ concentration $\left[\mathrm{SO}_{2}\right]$ and global radiation (GlobRad), and the sink term (CS) is condensation onto pre-existing aerosol particles. The scaling coefficient $k$ is based on the comparison of the proxy concentrations to the available measured sulfuric acid concentrations (Petäjä et al., 2009). 


\section{Atmospheric data analysis}

\subsection{Analysis of the diameter growth rates (GR) and the condensational mass fluxes to nucleation mode particles from particle size distribution data}

For the EUCAARI campaign in Hyytiälä and the Egbert measurement campaign, daily values for diameter growth rates (GR) of freshly-nucleated particles were determined from the DMPS and SMPS size distribution data by following the evolution of the geometric mean diameter of the nucleation mode, as described by Dal Maso et al. (2005). Corresponding mass fluxes to nucleation mode particles were estimated from the GR values using the median nucleation mode number concentrations during particle formation events, and an average particle density of $1500 \mathrm{~kg} \mathrm{~m}^{-3}$. The EUCAARI campaign data were also analysed for momentary (time resolution of $10 \mathrm{~min}$ ) diameter growth rates and mass fluxes by taking the running mean of geometric mean diameter change over $50 \mathrm{~min}$ for each size distribution measurement.

For the combined DMPS, BSMA and AIS data sets collected in Hyytiälä during 2003-2007, seasonal distributions of size-dependent GRs were determined with the method used by Hirsikko et al. (2005). To obtain the growth rates of particles in three size ranges, the GR analysis was done separately for size ranges $1.5-3 \mathrm{~nm}, 3-7 \mathrm{~nm}$ and $7-20 \mathrm{~nm}$. The smallest size range is not used for DMPS data and the largest size range is not used for BSMA data due to the detection limits of these instruments.

\subsection{The contribution of ambient sulfuric acid to the nucleation mode growth rates}

From the measured sulfuric acid concentration we can calculate the particle growth rate related to sulfuric acid condensation. Particle growth rate due to collision limited condensation of sulfuric acid is calculated according to the expression (Nieminen et al., 2010):

$\mathrm{GR}=\frac{m_{\mathrm{v}}}{2 \rho_{\mathrm{v}}}\left(1+\frac{d_{\mathrm{v}}}{d_{\mathrm{p}}}\right)^{2}\left(\frac{8 k T}{\pi}\right)^{1 / 2}\left(\frac{1}{m_{\mathrm{p}}}+\frac{1}{m_{\mathrm{v}}}\right)^{1 / 2} C_{\mathrm{v}}$

Here $m_{\mathrm{v}}, d_{\mathrm{v}}$ and $\rho_{\mathrm{v}}$ are the mass, diameter and liquid-phase density of the vapor molecule, respectively, $C_{\mathrm{v}}$ is the concentration, and $m_{\mathrm{p}}$ and $d_{\mathrm{p}}$ are the particle mass and diameter. The contribution of sulfuric acid to particle growth is then obtained as the ratio between the growth rate calculated by Eq. (2) and the observed particle growth rate.

\section{Model calculations}

\subsection{Aerosol microphysics box model}

To determine how the growth of ultrafine particles depends on the condensational behavior of SOA, we used a box-model version of the TwO-Moment Aerosol Sectional (TOMAS) microphysics algorithm (Adams and Seinfeld, 2002) driven by measurements at Hyytiälä and Egbert on particle formation event days. The model simulates the number of particles and mass of aerosol sulfate and aerosol organics within 36 lognormally spaced size bins between $3 \mathrm{~nm}$ and $10 \mu \mathrm{m}$. The modeled size distribution was initialized based on the measured size distribution just prior to the start of the nucleation event. The time-dependent new-particle formation rates at 3-nm were specified to the model based on the measurement data (Dal Maso et al., 2005). Time-dependent sulfuric-acid condensation onto the aerosol particles was specified in the Hyytiälä simulations using the measured concentrations of sulfuric acid. For the Egbert data, the time-dependent sulfuric-acid condensation was specified using the change in aerosol-sulfate mass measured by the AMS. The secondary organic aerosol (SOA) mass formation rate for both sites in the model was specified by the change in organic aerosol mass measured by the AMSs. Coagulation between particles is calculated online in TOMAS.

The new SOA was assumed to be a combination of effectively non-volatile species (where the SOA mass condenses kinetically onto the Fuchs-corrected surface area) and semi-volatile species (where the SOA mass instantaneously reaches thermodynamic equilibrium and partitions into the pre-existing mass). For the effectively non-volatile species case, the condensation of new SOA into each particle size bin $i$ was determined by

$$
\frac{d M_{\mathrm{LVSOA}, i}}{d t}=\frac{D_{\mathrm{p}, i}^{2} f\left(K n_{i}, \alpha_{\mathrm{m}}\right) N_{i}}{\sum_{j=1}^{36} D_{\mathrm{p}, j}^{2} f\left(K n_{j}, \alpha_{m}\right) N_{j}} \frac{d M_{\mathrm{SOA}, \text { total }}}{d t} f_{\mathrm{LV}}
$$

where $M_{\mathrm{SOA}}$ is the total mass of SOA, $t$ is time, $D_{\mathrm{p}}$ is the particle diameter, $f$ is the correction factor for particles outside of the kinetic size regime, $N$ is the number concentration, $K n$ is the particle Knudsen number, $\alpha_{\mathrm{m}}$ is the mass accommodation coefficient, and $f_{\mathrm{LV}}$ is the fraction of new SOA that is of low volatility. A mass accommodation coefficient of unity was always used in these cases. For the semi-volatile species, the condensation of new SOA into each particle size bin $i$ was determined by

$$
\frac{d M_{\mathrm{SVSOA}, i}}{d t}=\frac{D_{\mathrm{p}, i}^{3} N_{i}}{\sum_{j=1}^{36} D_{\mathrm{p}, j}^{3} N_{j}} \frac{d M_{\mathrm{SOA}, \text { total }}}{d t}\left(1-f_{\mathrm{LV}}\right) .
$$

Thus, the total OA mass is distributed evenly to the preexisting aerosol mass. As stated earlier, the total organic mass flux to the aerosol, $d M_{\mathrm{SOA}, \text { total }} / d t$, was determined from the AMS measurements. The fraction of this effectively non-volatile vs. semi-volatile organic aerosol was varied to match the measured growth rates and the final diameter of the secondary aerosols.

There were several important assumptions we made for this analysis: (1) the change in AMS-measured aerosol 
mass of sulfate or organics represents the total change in aerosol mass of those species. The AMS measures between about $40 \mathrm{~nm}$ to $1 \mu \mathrm{m}$, so we assume that condensation onto these sizes represents the dominant portion of the condensing mass; (2) the air mass is relatively homogeneous throughout the $10 \mathrm{~h}$ of the simulation; (3) the entrainment of free-tropospheric air into the boundary layer is negligible; (4) the semi-volatile aerosol equilibrates between the gas and aerosol phase instantaneously. In reality, there is a finite time for this to occur and it depends on the evaporation timescale for the SOA, which in turn depends on its volatility. We do not anticipate that these assumptions would change the major conclusion that semi-volatile SOA that instantaneously reaches thermodynamic equilibrium and partitions to preexisting mass cannot explain nanoparticle growth observed on these nucleation days.

\subsection{Global chemical transport model Geos-Chem}

Global modelling of the sensitivity of $\mathrm{CCN}$ to the SOA condensational behavior was done using the chemical-transport model GEOS-CHEM (Bey et al., 2001) with the online size-resolved aerosol microphysics module TOMAS (Adams and Seinfeld, 2002; Trivitayanurak et al., 2008; Pierce and Adams, 2009). The model simulates aerosols and gases in the atmosphere with $4 \times 5$ degree horizontal resolution and 30 vertical layers extending from the surface to $0.01 \mathrm{hPa}$. The aerosol size distribution is calculated across 40 lognormally spaced size sections spanning $1 \mathrm{~nm}$ to $10 \mu \mathrm{m}$. Within each size section, TOMAS predicts the number of particles and the mass of 7 aerosol species (sulfate, sea-salt, hydrophilic organics, hydrophobic organics, internally mixed black carbon, externally mixed black carbon and dust). The aerosol size distribution is shaped by new-particle formation, condensation of sulfate and organic vapors, coagulation of particles, aqueous-phase chemistry, wet deposition and dry deposition. New-particle formation rates were calculated in the boundary layer using semi-empirical nucleation parameterization where nucleation rate depends linearly on sulfuric acid concentration (Sihto et al., 2006) with a pre-factor of $2 \times 10^{-6} \mathrm{~cm}^{-3} \mathrm{~s}^{-1}$ (Spracklen et al., 2006) and in the free troposphere using parameterization of classical nucleation theory for sulfuric acid and water nucleation (Vehkamäki et al., 2002). $10 \%$ of biogenic terpenes are assumed to form SOA in these model simulations. This corresponds to an annual SOA formation rate of $18 \mathrm{Tg} \mathrm{yr}^{-1}$. Upon SOA formation, the new SOA is assumed to be a combination of low-volatility species (where the SOA mass condenses onto the Fuchs-corrected surface area) and semi-volatile species (where the SOA mass partitions into the pre-existing mass). The amount of semivolatile organics in the aerosol phase does not depend on the OA mass. This assumption allows us to keep the amount of organic aerosol formed in the model constant between simulations where the fraction of effectively non-volatile versus semi-volatile SOA is varied.
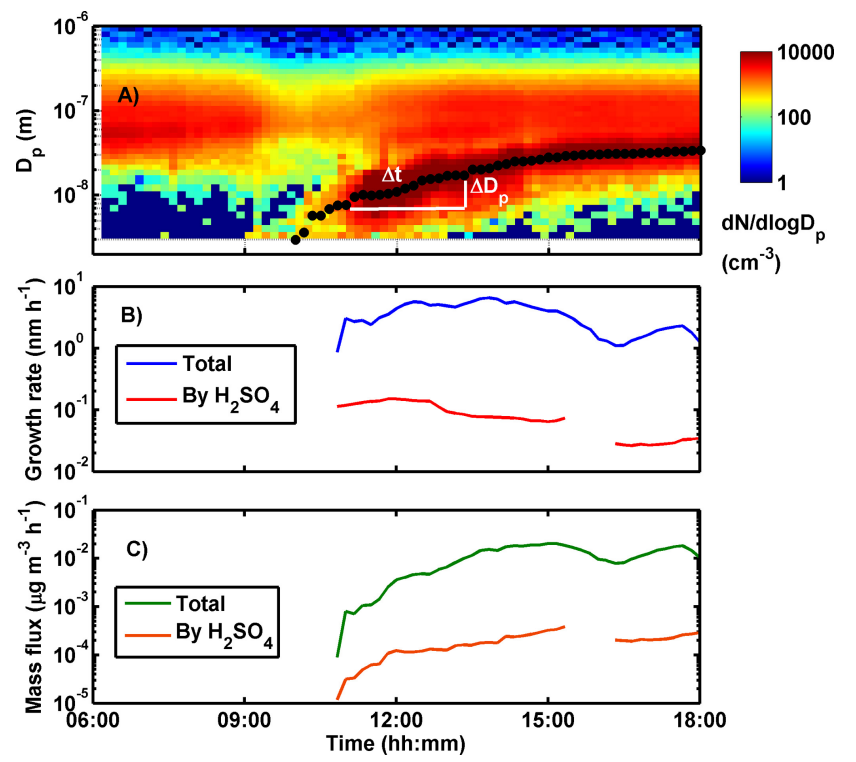

Fig. 2. Aerosol formation and growth event on 15 April 2007 at the SMEAR II station in Hyytiälä, Finland. (A) Evolution of aerosol number size distribution. The black dots represent the geometric mean size of the nucleation mode. (B) Particle diameter growth rate $\left(\mathrm{GR}=\Delta D_{\mathrm{p}} / \Delta t\right)$ and $(\mathbf{C})$ mass flux to the nucleation mode as determined from the data and calculated based on ambient sulfuric acid concentrations. The GR and mass flux by sulfuric acid are theoretical maximum values.

There are large uncertainties in the emissions of SOA precursor gases in all atmospheric models (see e.g. Hallquist et al., 2006). Many models, including the version of GEOSCHEM used here, do not include anthropogenic- and marineSOA-precursor emissions as well as multi-generational aging of SOA. Furthermore, the sources of biogenic SOA are still quite uncertain. Further work is necessary to determine if SOA formed from other precursor gases also has a high fraction of low-volatility species and a similar ability to grow ultrafine particles.

\section{Nucleation mode growth and organic condensation}

Figure 2a shows the measured evolution of aerosol particle size distribution during a nucleation and growth event in Hyytiälä, Finland. In the morning new particles start to appear, growing by condensation. The diameter growth rate (GR) of the nucleation mode and the corresponding mass flux are shown in Fig. 2b and c, along with the maximum GR and mass flux corresponding to the ambient sulfuric acid concentrations. Sulfuric acid can only explain a small fraction of the particle growth: the rest is due to other compounds, presumably organics. The same behavior was observed in all 38 Hyytiälä events analyzed (Table 1).

The monthly median GRs and mass fluxes to nucleation mode particles for 2003-2007 in Hyytiälä are shown in 
Table 1. The median and quartile growth rates and mass fluxes in Hyytiälä during years 2003-2007, along with the corresponding growth rates and mass fluxes explained by ambient sulfuric acid concentrations.

\begin{tabular}{ccccccc}
\hline & $\begin{array}{c}\mathrm{GR} \text { from data } \\
\left(\mathrm{nm} \mathrm{h}^{-1}\right)\end{array}$ & $\begin{array}{c}\text { Mass flux from } \\
\text { data }\left(\mu \mathrm{g} \mathrm{m}^{-3} \mathrm{~h}^{-1}\right)\end{array}$ & $\begin{array}{c}\mathrm{GR} \mathrm{by} \mathrm{H}_{2} \mathrm{SO}_{4} \\
\left(\mathrm{~nm} \mathrm{~h}^{-1}\right)\end{array}$ & $\begin{array}{c}\text { Mass flux by } \\
\mathrm{H}_{2} \mathrm{SO}_{4}\left(\mu \mathrm{g} \mathrm{m}^{-3} \mathrm{~h}^{-1}\right)\end{array}$ & $\begin{array}{c}\text { Fraction of GR } \\
\text { by } \mathrm{H}_{2} \mathrm{SO}_{4}\end{array}$ & $\begin{array}{c}\text { Fraction of mass } \\
\text { flux by } \mathrm{H}_{2} \mathrm{SO}_{4}\end{array}$ \\
\hline 25-percentile & 1.6 & $8 \times 10^{-4}$ & 0.02 & $2 \times 10^{-5}$ & $1 \%$ & $1 \%$ \\
50-percentile & 2.3 & $2 \times 10^{-3}$ & 0.03 & $3 \times 10^{-5}$ & $2 \%$ & $3 \%$ \\
75-percentile & 2.9 & $5 \times 10^{-3}$ & 0.05 & $7 \times 10^{-5}$ & $4 \%$ & $5 \%$ \\
\hline
\end{tabular}
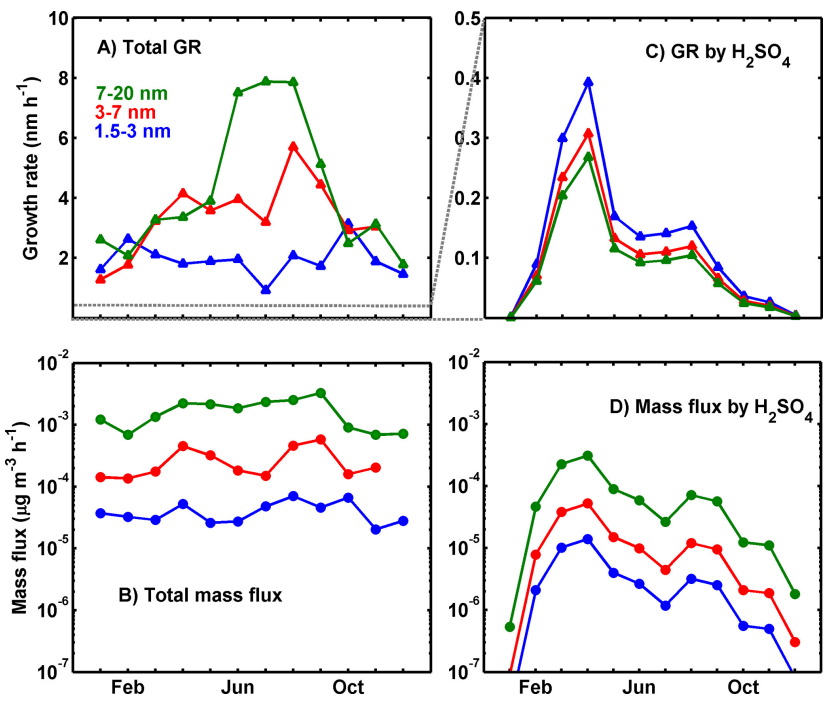

Fig. 3. Seasonal distribution of nucleation mode diameter growth rates (GR) and mass fluxes in 2003-2007. Median GRs (A) and mass fluxes (B) to 1.5-3, 3-7 and 7-20 nm particles as determined from size distribution data. Median GRs (C) and mass fluxes (D) to nucleation mode aerosol as calculated from estimated ambient sulfuric acid concentration.

Fig. 3. The GRs of 3-20 nm particles have a seasonal dependence, peaking in the summer when the emissions of biogenic organics and their photochemical oxidation are maximal. This reinforces our conclusion that organics govern the growth of small particles to climatically relevant sizes. The growth is enhanced as the particles get larger, and GRs explained by sulfuric acid condensation are consistently lower and show a different seasonal pattern as compared with the observations. Ambient sulfuric acid concentrations could explain on average $7 \%$ (9), $3 \%$ (5), and $2 \%$ (4) of the GRs (mass fluxes) of 1-3, 3-7 and 7-20 nm particles. For comparison, the total aerosol mass concentration and the fraction of organic, nitrate and sulfate aerosol as recorded with the AMS during spring 2007 in Hyytiälä are presented in Fig. 4. The total organic aerosol mass fluxes to $>20 \mathrm{~nm}$ particles as calculated from the AMS data ranged from 0.02$0.2 \mu \mathrm{g} \mathrm{m}^{-3} \mathrm{~h}^{-1}$ for spring 2007 in Hyytiälä. The mass required to grow the nucleation mode particles is thus usually less than $10 \%$ of the total condensing OA mass.

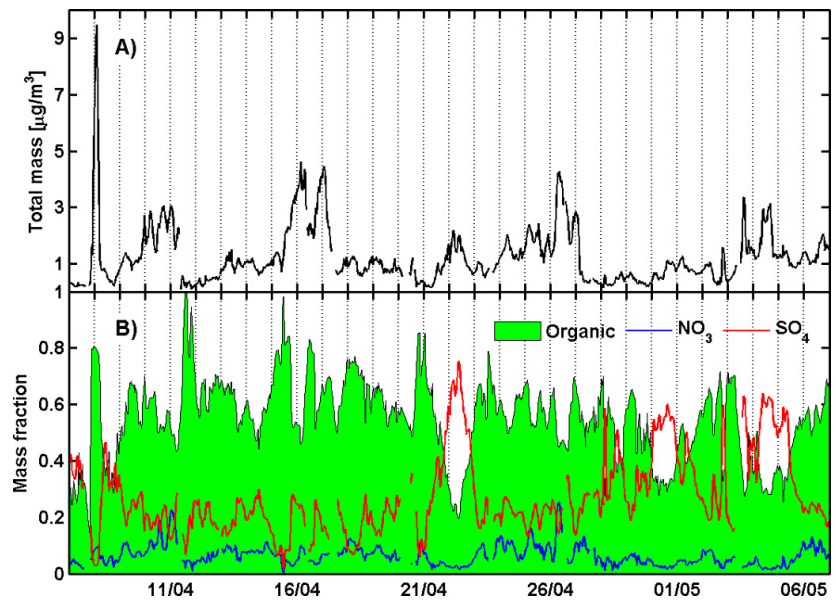

Fig. 4. The total aerosol mass concentration (A) and the fraction of organic, nitrate and sulphate aerosol (B) as recorded with the AMS during spring 2007 in Hyytiälä, Finland.

We analyzed 5 particle formation event days observed in Hyytiälä and 2 in Egbert in more detail with the box model simulating the evolution of the aerosol size distribution (see Sect. 4.1). Particle growth was modeled by letting a fraction (representative of effectively non-volatile organics) of the total organic mass flux condense kinetically to the aerosol surface area ("kinetic" fraction), while the rest of the OA (representative of semi-volatile organics) was distributed according to the pre-existing OA mass ("thermodynamic" absorptive fraction).

The evolution of the measured and modeled aerosol size distribution for Hyytiälä on 15 April 2007 is shown in Fig. 5. When SOA is assumed to be semi-volatile and partitions entirely to the pre-existing mass (top right panel), the newly formed particles do not grow to the measured sizes. However, when $50 \%-100 \%$ (bottom panels) of the organic aerosol is assumed to be effectively non-volatile on this day, we have better predictions of the growth of these particles. The result thus implies the growth to be limited by the gas phase concentrations of the condensing species rather than their equilibrium vapour pressures. Snapshots of the observed and modeled number and mass size distributions during particle growth on the same day are presented in Fig. 6. 


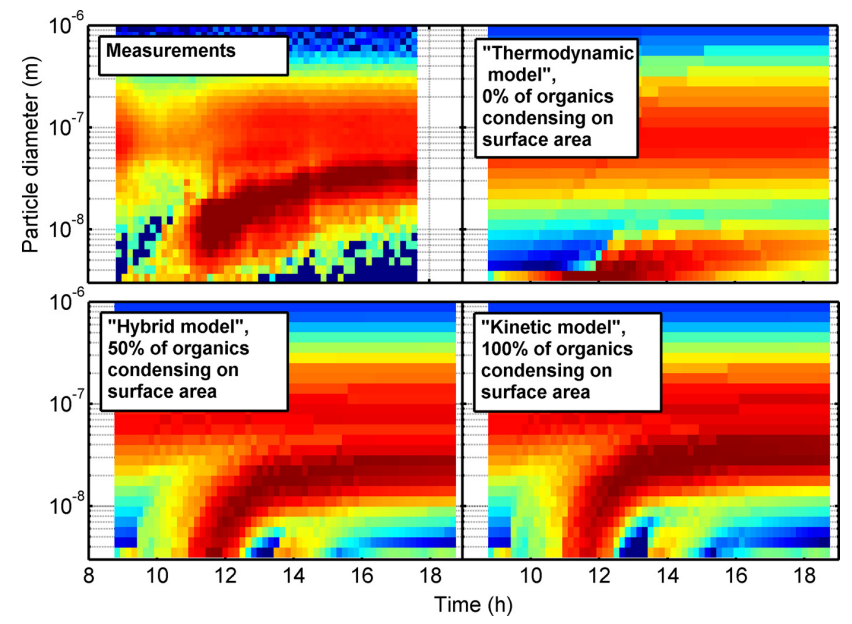

Fig. 5. A comparison between the evolution of the atmospheric size distribution on 15 April 2007 in Hyytiälä (top left) with the box model calculations assuming $0 \%$ (top right); $50 \%$ (bottom left); $100 \%$ (bottom right) of the organic mass to condense on the aerosol surface area. In the top right panel only sulfuric acid is condensing on the surface area of the aerosol - the organics are distributed to the pre-existing mass.

On this day, 50\%-50\% division between "thermodynamic" (absorptive) and "kinetic" organics yielded the best agreement between observed and modeled particle growth. The choice of the condensation scheme has a significant impact on the predicted number size distribution, the mass-based partitioning ("thermodynamic model") performing clearly worst. The bottom panel of Fig. 6 depicts the size-dependent composition of freshly-formed aerosol particles during their growth on 15 April 2007. If half of the OA mass is assumed to condense by kinetic collisions to the surface area, the nucleation mode $\left(D_{\mathrm{p}}<30 \mathrm{~nm}\right)$ aerosol is predicted to consist of almost solely of this low-volatility organic component.

The comparison between the measured and the modeled particle growth rates and mass fluxes to the nucleation mode with varying fraction of the SOA condensing onto the surface area are presented in Fig. 7. The division of the SOA to the "kinetic" and the "thermodynamic" absorptive fractions corresponding to the best fits between measurements and model calculations are given in Table 2. Over all the analyzed days, $20-50 \%$ of the total OA mass flux needed to be distributed to the particle surface area to explain the observed growth.

\section{Discussion and global implications}

The results on the important role of organics in ultrafine aerosol growth are complemented by a number of observations. Allan et al. (2006) reported that $>40 \mathrm{~nm}$ particles from particle formation events in Hyytiälä during spring 2003 consisted principally of organics. Water-uptake measurements suggest organic contribution even in particles as small as

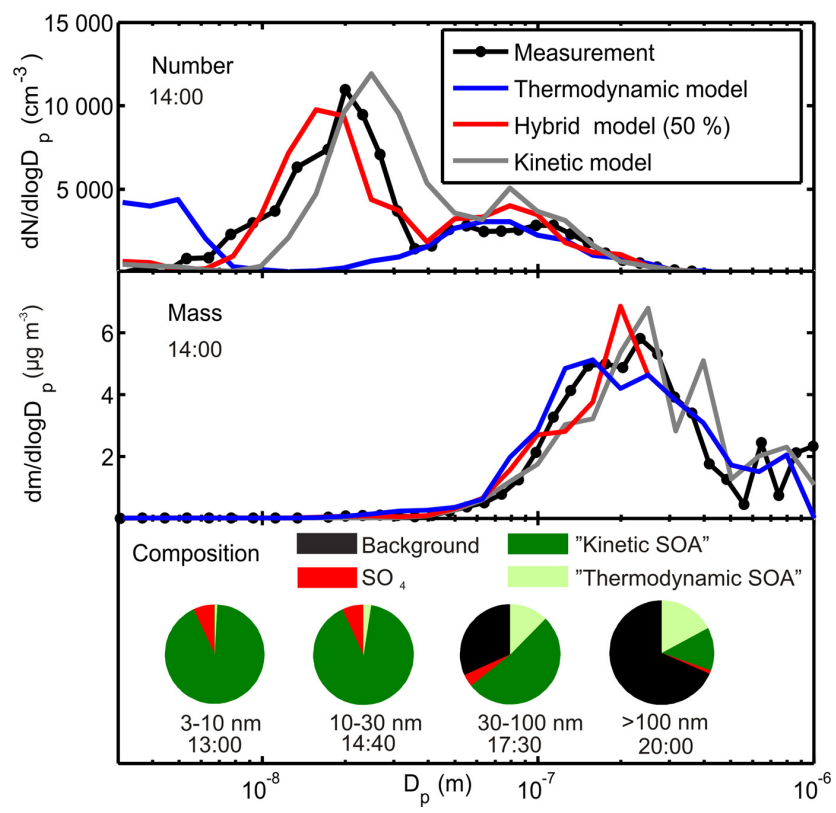

Fig. 6. Predictions of aerosol number (top) and mass (middle) size distributions and jcompositions (bottom) during aerosol growth on 15 April 2007 in Hyytiälä, Finland. The black curve corresponds to observations, the blue to the case where only sulfuric acid condenses on the aerosol surface area and the organics are distributed in the pre-existing aerosol mass ("Thermodynamic model"), the red and gray to the cases where $50 \%$ (best fit, "Hybrid model") or $100 \%$ ("Kinetic model") of the total organic flux was distributed to the aerosol surface area. The pie charts indicate the simulated aerosol composition at the time of maximum concentration in 3-10, 10-30, $30-100$ and $>100 \mathrm{~nm}$ particles corresponding for the Hybrid model (50\%). "Background" refers to the initial particle size distribution obtained from the DMPS data where the size-dependent composition was unknown.

2-4 nm (Kulmala et al., 2007; Riipinen et al., 2009). Kuang et al. (2010) reported the contribution of sulfuric acid to the nucleation-mode particle GR to be less than $10 \%$ at various continental sites. Jimenez et al. (2009) divided oxidized OA to semi- and low-volatility components (SV-OOA and LVOOA) - typical mass ratio between the two in Hyytiälä being about 50\%-50\%. The thermodynamically (absorptively) partitioning and kinetically condensing organics defined in this study are thus probably connected to these SV- and LVOOA components, LV-OOA being of particular importance in ultrafine aerosol growth. Our results are also in line with a recent global modeling study by $\mathrm{Yu}$ (2011), who also found that a significant contribution of low-volatility organics is needed to explain atmospheric growth rates. Organics may participate in atmospheric nucleation as well (O'Dowd et al., 2002; Metzger et al., 2010).

There are indications that nucleation-mode particles contain material that seems to be of very low volatility - at least after heating (e.g. Ehn et al., 2007). The V-DMPS data collected from Hyytiälä are consistent with these observations: 
Table 2. The particle formation events analyzed in detail with the aerosol dynamics box model, along with the particle growth rates determined from the observational data and the simulated evolution of the freshly-formed nucleation mode corresponding to the best fit between the observations and the modeled growth.

\begin{tabular}{llccr}
\hline Site & Date & $\begin{array}{c}\text { GR from } \\
\text { data } \\
\left(\mathrm{nm} \mathrm{h}^{-1}\right)\end{array}$ & $\begin{array}{c}\text { GR from } \\
\text { simulations } \\
\left(\mathrm{nm} \mathrm{h}^{-1}, \text { best fit }\right)\end{array}$ & $\begin{array}{r}\text { Fraction of OA to } \\
\text { to surface area } \\
\text { (best fit) }\end{array}$ \\
\hline Hyytiälä & 9 April 2007 & 1.3 & 1.4 & $20 \%$ \\
Hyytiälä & 10 April 2007 & 4.0 & 3.9 & $40 \%$ \\
Hyytiälä & 15 April 2007 & 6.3 & 6.5 & $50 \%$ \\
Hyytiälä & 16 April 2007 & 2.8 & 3.4 & $30 \%$ \\
Hyytiälä & 5 May 2007 & 3.4 & 3.2 & $100 \%$ \\
Egbert & 21 May 2007 & 3.7 & 3.5 & $30 \%$ \\
Egbert & 22 May 2007 & 5.2 & 4.1 & $100 \%$ \\
\hline
\end{tabular}
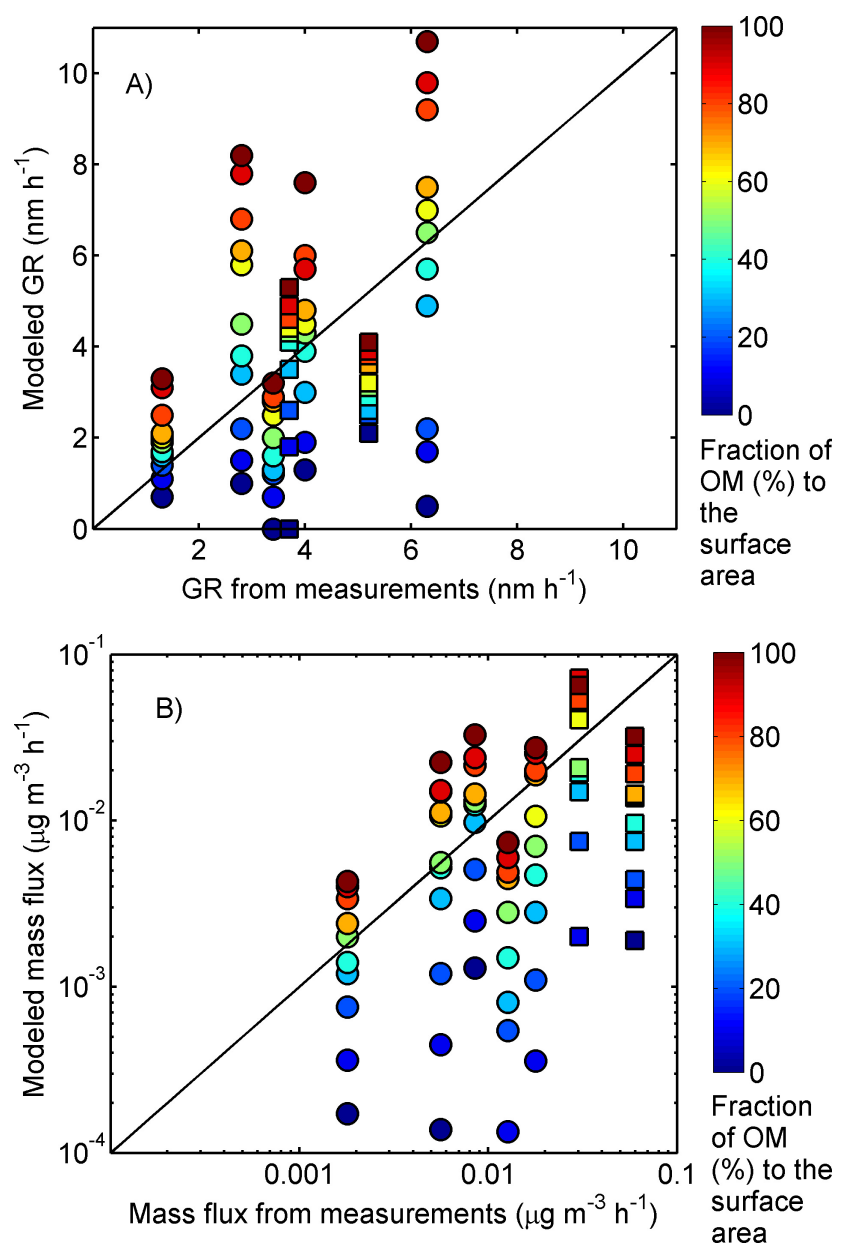

Fig. 7. Particle growth rates (A) and mass fluxes (B) as determined from the measurement data and the model simulations for 7 particle formation event days in Hyytiälä and Egbert (see Table 2). The color scale depicts the fraction of total OA mass flux that was distributed on aerosol surface area in each of the simulations.

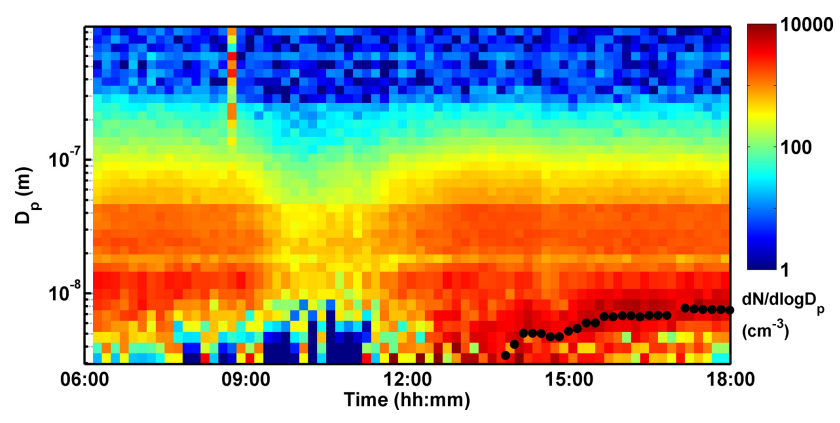

Fig. 8. The contribution of low-volatility material to the nucleation mode growth in Hyytiälä during an atmospheric nucleation event on 15 April 2007. The particle size distributions measured with the V-DMPS system after the ambient aerosol sample has been heated to $280^{\circ} \mathrm{C}$. The black dots represent the geometric mean size of the growing nucleation mode after heating.

on all nucleation event days in Hyytiälä the growing nucleation mode contained material that did not evaporate at $280^{\circ} \mathrm{C}$ (see Fig. 8 for an example). Examples of potential formation mechanisms of these low-volatility compounds are reactions between amines and organic acids (Barsanti et al., 2009) or polymerization in the particles (Kalberer et al., 2004). It is also possible that this apparent non-volatility is due to mass-transfer limitations in solid or amorphous particles (Virtanen et al., 2010).

Our results suggest that thermodynamic equilibrium approaches are insufficient for modeling organic contribution to atmospheric particle numbers: the kinetics of the masstransfer need to be considered as well. To develop a processlevel understanding of the ultrafine aerosol growth, future work is needed to investigate (1) the equilibrium vapor pressures of the nucleation-mode constituents; (2) the processes forming these compounds in the atmosphere; (3) their kinetics in both gas and particulate phases. 

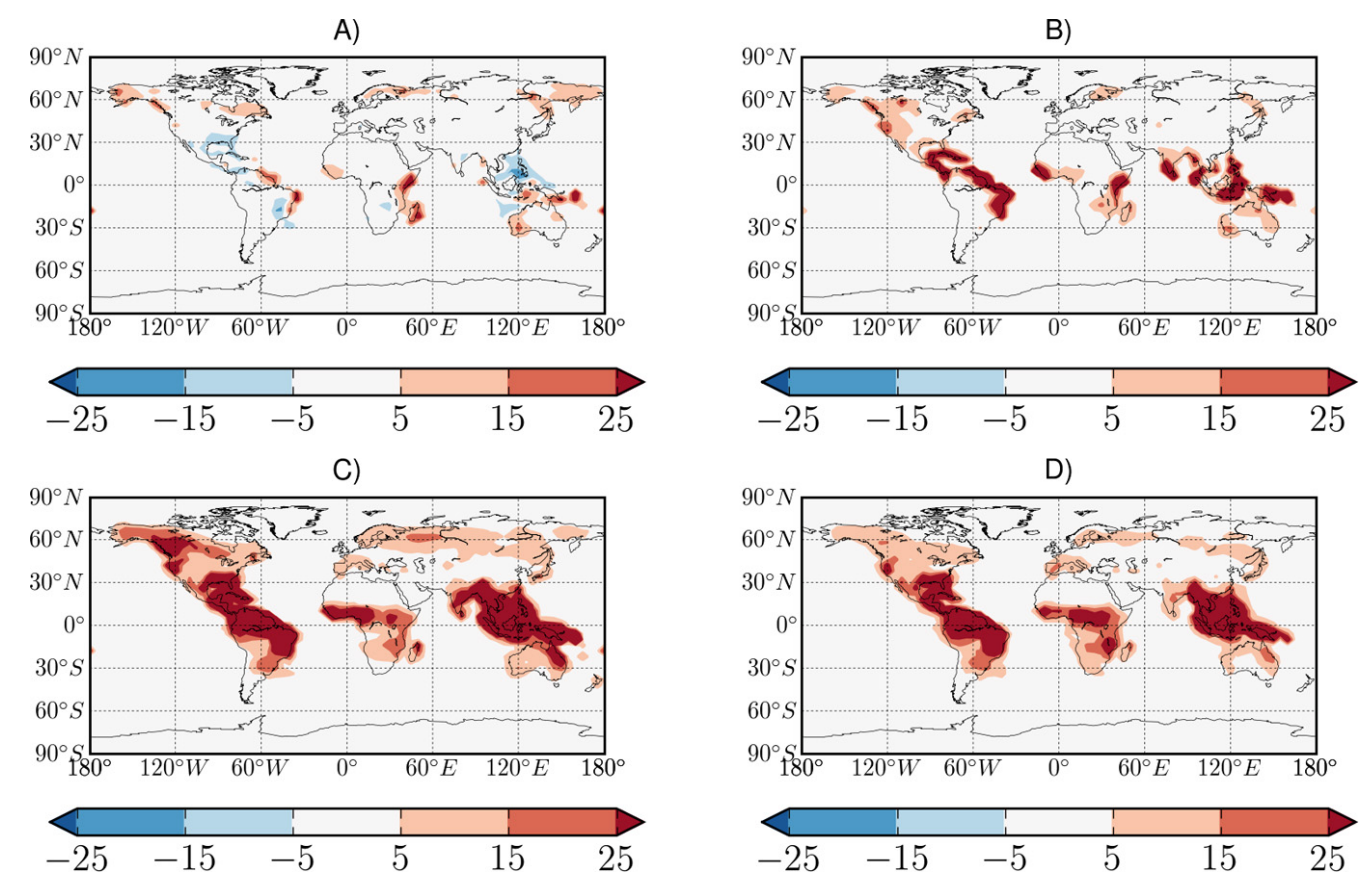

Fig. 9. Increases in aerosol number concentrations due to ultrafine aerosol growth by semi-empricial organic condensation scheme for June 2001. Changes in global aerosol number concentrations (average over $1 \mathrm{~km}$ ) if $50 \%$ of the total OA mass is distributed as effectively non-volatile, as compared with the case where it partitions to the pre-existing aerosol mass. The colorscale indicates percentage changes in number concentrations of particles $>3 \mathrm{~nm}(\mathbf{A}),>10 \mathrm{~nm}(\mathbf{B}),>40 \mathrm{~nm}(\mathbf{C})$, and $>80 \mathrm{~nm}$ (D).
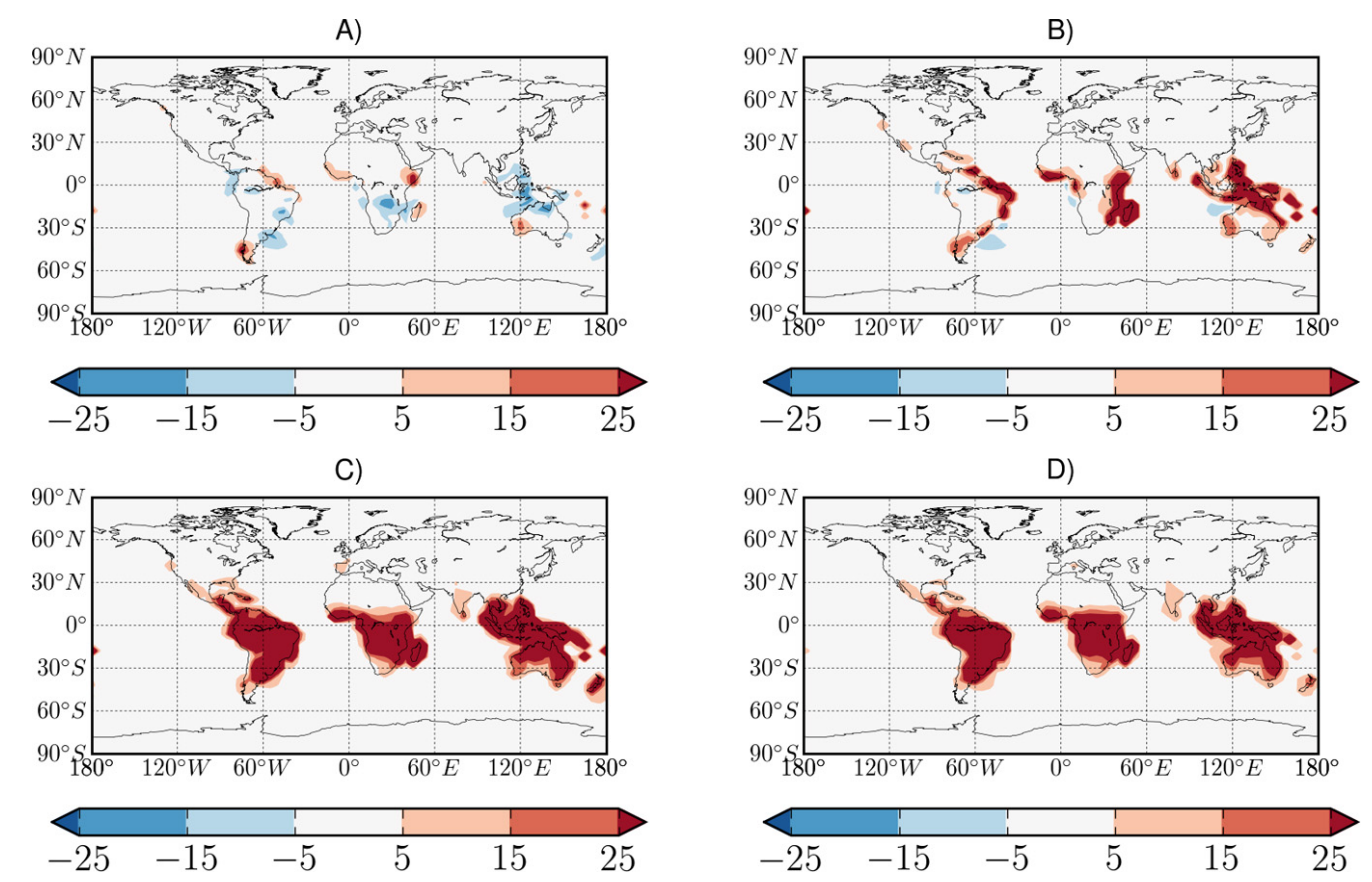

Fig. 10. Increases in aerosol number concentrations due to ultrafine aerosol growth by semi-empirical organic condensation scheme for March 2001. Changes in global aerosol number concentrations (average over $1 \mathrm{~km}$ ) if $50 \%$ of the total OA mass is distributed as effectively non-volatile, as compared with the case where is partitions to the pre-existing aerosol mass. The colorscale indicates percentage changes in number concentrations of particles $>3 \mathrm{~nm}(\mathbf{A}),>10 \mathrm{~nm}(\mathbf{B}),>40 \mathrm{~nm}(\mathbf{C})$, and $>80 \mathrm{~nm}($ D) . 

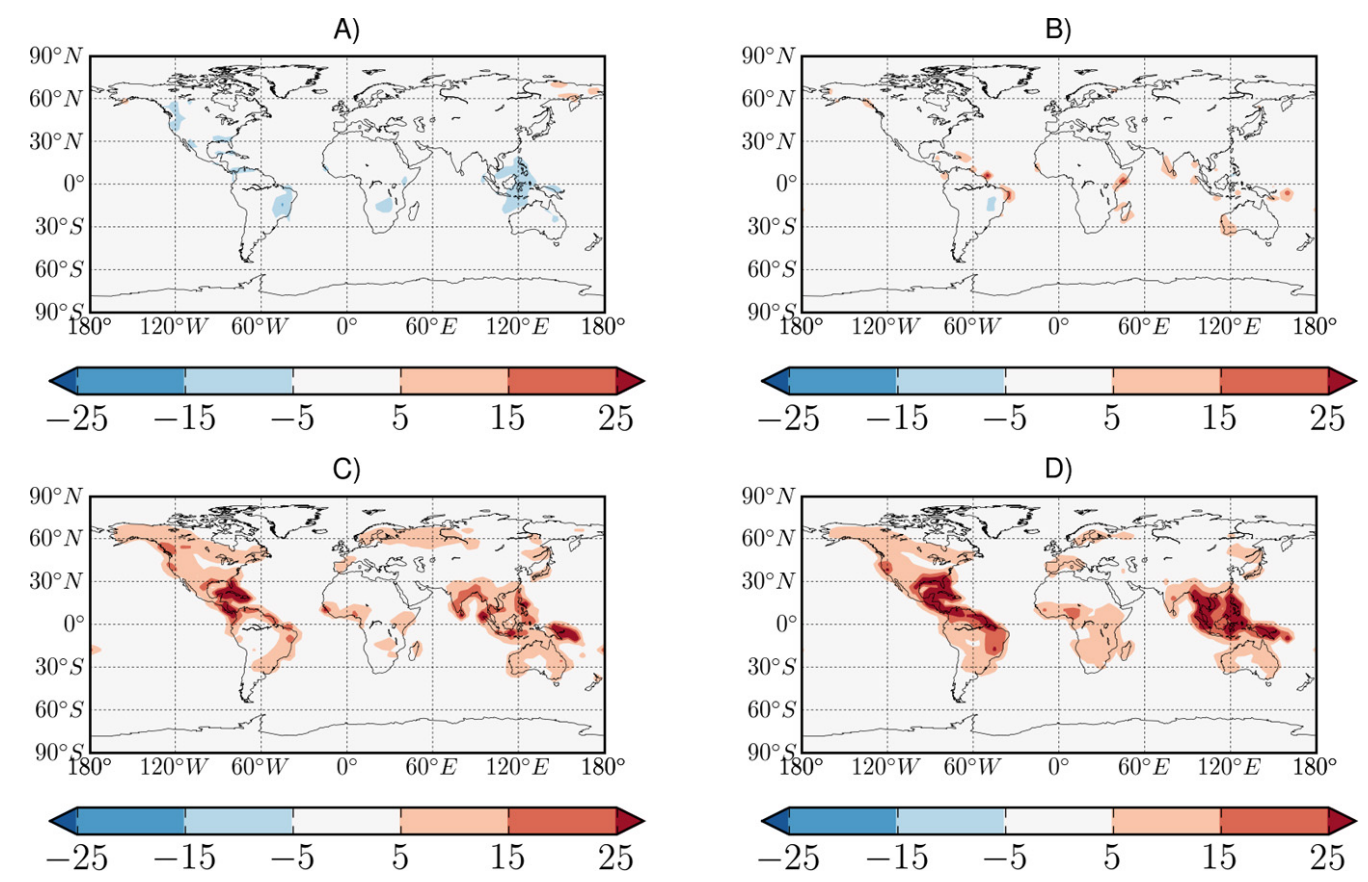

Fig. 11. Increases in aerosol number concentrations due to ultrafine aerosol growth by fully kinetic condensation approach as compared with the semi-empirical scheme for June 2001. Changes in global aerosol number concentrations (average over $1 \mathrm{~km}$ ) if all of the total OA mass is distributed as effectively non-volatile, as compared with the case where $50 \%$ of it partitions to the pre-existing aerosol mass. The colorscale indicates percentage changes in number concentrations of particles $>3 \mathrm{~nm}(\mathbf{A}),>10 \mathrm{~nm}(\mathbf{B}),>40 \mathrm{~nm}(\mathbf{C})$, and $>80 \mathrm{~nm}(\mathbf{D})$.

The global implications of our results are illustrated in Figs. 9-11, where the impact of the enhanced ultrafine particle growth is shown as predicted with the chemical transport model GEOS-Chem for June 2001 (Figs. 9 and 11) and March 2001 (Fig. 10). Figure 9 displays the change in global number concentrations of aerosol particles, if $50 \%$ of the secondary OA mass is directed to the particle surface area, as compared with the simulation where all of it is partitioned to the pre-existing organic mass. For the concentrations of particles larger than $40-80 \mathrm{~nm}$, increases over $25 \%$ are seen for extensive regions, suggesting similar effects on the $\mathrm{CCN}$ concentrations. This effect is comparable to estimates on the overall impact of nucleation on global particle number concentrations (Merikanto et al., 2009) and the resulting effect on the total-sky atmospheric radiative forcing due to the first indirect aerosols effect can be well over $1 \mathrm{Wm}^{-2}$ in areas with frequent stratus cloud cover (Seinfeld and Pandis, 2006, Eq. 24.43). The globally averaged change in the number of particles larger than $3 \mathrm{~nm}, 10 \mathrm{~nm}, 40 \mathrm{~nm}$ and $80 \mathrm{~nm}$ are $1.2 \%, 2.8 \%, 8.8 \%$ and $6.6 \%$, respectively. The impact of the enhanced growth is similar but less pronounced in March 2001 (Fig. 10). For March, the globally averaged change in the number of particles larger than $3 \mathrm{~nm}, 10 \mathrm{~nm}$, $40 \mathrm{~nm}$ and $80 \mathrm{~nm}$ are $-1.0 \%, 1.9 \%, 6.2 \%$ and $5.2 \%$. The comparison between the fully kinetic condensation approach and the 50\%-50\% division is presented in Fig. 11. In this case, the globally averaged change in the number of particles larger than $3 \mathrm{~nm}, 10 \mathrm{~nm}, 40 \mathrm{~nm}$ and $80 \mathrm{~nm}$ are $-1.6 \%$,
$0.0 \%, 3.9 \%$ and $4.4 \%$. When particle number concentrations are considered, the fully kinetic condensation approach and the 50\%-50\% division result in similar predictions than the 50\%-50\% results and the thermodynamic absorptive equilibrium approach. It is known, however, that particularly with anthropogenic organic matter the assumption of completely non-volatile material is likely to result in incorrect predictions (Robinson et al., 2007).

Organics account for a major fraction of the growth of ultrafine particles. Based on atmospheric data on particle GRs, we have developed a semi-empirical approach to model this growth. We have demonstrated that neglecting the organic condensation onto ultrafine aerosol can result in significant under-predictions of $\mathrm{CCN}$-sized aerosol numbers. More global measurements concentrating on ultrafine particle growth, along with studies developing a mechanistic understanding of both the kinetics and the thermodynamics of atmospheric condensation are necessary to reliably constrain the impact of OA on climate.

Acknowledgements. Henry and Camille Dreyfus foundation, Maj and Tor Nessling foundation, Academy of Finland Centre of Excellence program (project no. 1118615) and the European Commission 7th framework programme EUCAARI (contract no. 036833-2) are acknowledged. The Egbert measurements were supported by Environment Canada and the Canadian Foundation for Climate and Atmospheric Sciences, through the CAFC network.

Edited by: U. Pöschl 


\section{References}

Aalto, P., Hämeri, K., Becker, E., Weber, R., Salm. J., Mäkelä, J. M., Hoell, C., O’Dowd, C., Karlsson, H., Hansson, H-C., Väkevä, M., Koponen, I., Buzorius, G., and Kulmala, M.: Physical characterisation of aerosol particles during nucleation events, Tellus, 53B, 344-358, 2001.

Adams, P. J. and Seinfeld, J. H.: Predicting global aerosol size distributions in general circulation models, J. Geophys. Res., 107, 4370, doi:10.1029/2001JD001010, 2002.

Allan, J. D., Alfarra, M. R., Bower, K. N., Coe, H., Jayne, J. T., Worsnop, D. R., Aalto, P. P., Kulmala, M., Hyötyläinen, T., Cavalli, F., and Laaksonen, A.: Size and composition measurements of background aerosol and new particle growth in a Finnish forest during QUEST 2 using an Aerodyne Aerosol Mass Spectrometer, Atmos. Chem. Phys., 6, 315-327, doi:10.5194/acp-6-315-2006, 2006.

Barsanti, K. C., McMurry, P. H., and Smith, J. N.: The potential contribution of organic salts to new particle growth, Atmos. Chem. Phys., 9, 2949-2957, doi:10.5194/acp-9-2949-2009, 2009.

Bey, I., Jacob, D. J., Yantosca, R. M., Logan, J. A., Field, B., Fiore, A. M., Li, Q., Liu, H., Mickley, L. J., and Schultz, M.: Global modeling of tropospheric chemistry with assimilated meteorology: Model description and evaluation, J. Geophys. Res., 106(D19), 23073-23096, 2001.

Canagaratna, M. R., Jayne, J. T., Jimenez, J. L., Allan, J. D., Alfarra, M. R., Zhang, Q., Onasch, T. B., Drewnick, F., Coe, H., Middlebrook, A., Delia, A., Williams, L. R., Trimborn, A. M., Northway, M. J., DeCarlo, P. F., Kolb, C. E., Davidovits, P., and Worsnop, D. R.: Chemical and microphysical characterization of ambient aerosols with the aerodyne aerosol mass spectrometer, Mass Spectrom. Rev., 26, 185-222, 2007.

Clement, A. C., Burgman, R., and Norris, J. R.: Observational and Model Evidence for Positive Low-Level Cloud Feedback, Science, 325, 460-464, 2009.

Cross, E. S., Slowik, J. G., Davidovits, P., Allan, J. D., Worsnop, D. R., Jayne, J. T., Lewis, D. K., Canagaratna, M., and Onasch, T. B.: Laboratory and Ambient Particle Density Determinations using Light Scattering in Conjunction with Aerosol Mass Spectrometry, Aerosol Sci. Technol., 41, 343-359, doi:10.1080/02786820701199736, 2007.

Cross, E. S., Onasch, T. B., Canagaratna, M., Jayne, J. T., Kimmel, J., Yu, X.-Y., Alexander, M. L., Worsnop, D. R., and Davidovits, P.: Single particle characterization using a light scattering module coupled to a time-of-flight aerosol mass spectrometer, Atmos. Chem. Phys., 9, 7769-7793, doi:10.5194/acp-9-7769-2009, 2009.

Dal Maso, M., Kulmala, M., Riipinen, I., Wagner, R., Hussein, T., Aalto, P. P., and Lehtinen, K. E. J.: Formation and growth of fresh atmospheric aerosols: eight years of aerosol size distribution data from SMEAR II, Hyytiälä, Finland, Boreal Environ. Res., 10, 323-336, 2005.

Donahue, N. M., Robinson, A. L., Stanier, C. O., and Pandis, S. N.: Coupled Partitioning, Dilution, and Chemical Aging of Semivolatile Organics, Environ. Sci. Technol., 40, 2635-2643, 2006.

Drewnick, F., Hings, S. S., DeCarlo, P. F., Jayne, J. T., Gonin, M., Fuhrer, K., Weimer, S., Jimenez, J. L., Demerjian, K. L., Borrmann, S., and Worsnop, D. R.: A new Time-of-Flight Aerosol
Mass Spectrometer (ToF-AMS) - Instrument description and first field deployment, Aerosol Sci. Technol., 39, 637-658, 2005.

Drewnick, F., Hings, S. S., Curtius, J., Eerdekens, G., and Williams, $\mathrm{J}$.: Measurement of fine particulate and gas phase species during the New Year's Fireworks 2005 in Mainz, Germany, Atmos. Environ., 40, 4316-4327, 2006.

Dusek, U., Frank, G. P., Hildebrandt, L., Curtius, J., Schneider, J., Walter, S., Chand, D., Drewnick, F., Hings, S., Jung, D., Borrmann, S., and Andreae, M. O.: Size Matters More Than Chemistry for Cloud-Nucleating Ability of Aerosol Particles, Science, 312, 1375-1378, 2006.

Ehn, M., Petäjä, T., Birmili, W., Junninen, H., Aalto, P., and Kulmala, M.: Non-volatile residuals of newly formed atmospheric particles in the boreal forest, Atmos. Chem. Phys., 7, 677-684, doi:10.5194/acp-7-677-2007, 2007.

Ehn, M., Junninen, H., Schobesberger, S., Manninen, H., Franchin A., Sipilä, M., Petäjä, T., Kerminen, V.-M., Tammet, H., Mirme, A., Mirme, S., Hõrrak, U., Kulmala, M., and Worsnop, D. R.: An instrumental comparison of mobility and mass measurements of atmospheric small ions, Aerosol Sci. Tech., 45, 522-532, 2011.

Goldstein, A. E. and Galbally, I. E.: Known and Unexplored Organic Constituents in the Earth's Atmosphere, Environ. Sci. Technol., 41, 1514-1521, 2007.

Hallquist, M., Wenger, J. C., Baltensperger, U., Rudich, Y., Simpson, D., Claeys, M., Dommen, J., Donahue, N. M., George, C., Goldstein, A. H., Hamilton, J. F., Herrmann, H., Hoffmann, T., Iinuma, Y., Jang, M., Jenkin, M. E., Jimenez, J. L., Kiendler-Scharr, A., Maenhaut, W., McFiggans, G., Mentel, Th. F., Monod, A., Prévôt, A. S. H., Seinfeld, J. H., Surratt, J. D., Szmigielski, R., and Wildt, J.: The formation, properties and impact of secondary organic aerosol: current and emerging issues, Atmos. Chem. Phys., 9, 5155-5236, doi:10.5194/acp-95155-2009, 2009.

Hari, P. and Kulmala, M.: Station for measuring ecosystematmosphere relations (SMEAR II), Boreal Env. Res. 10, 315322, 2005.

Hirsikko, A., Laakso, L, Hõrrak, U., Aalto, P. P., Kerminen, V.M., and Kulmala, M.: Annual and size dependent variation of growth rates and ion concentrations in boreal forest, Boreal Env. Res., 10, 357-369, 2005.

Hirsikko, A., Bergman, T., Laakso, L., Dal Maso, M., Riipinen, I., Hõrrak, U., and Kulmala, M.: Identification and classification of the formation of intermediate ions measured in boreal forest, Atmos. Chem. Phys., 7, 201-210, doi:10.5194/acp-7-201-2007, 2007.

Intergovernmental Panel on Climate Change (IPCC): Climate Change 2007 - The Physical Science Basis: Contribution of Working Group I to the Fourth Assessment Report of the IPCC, Cambridge, Cambridge University Press, 2007.

Jimenez, J. L., Canagaratna, M. R., Donahue, N. M., Prevot, A. S. H., Zhang, Q., Kroll, J. H., DeCarlo, P. F., Allan, J. D., Coe, H., Ng, N. L., Aiken, A. C., Docherty, K. S., Ulbrich, I. M., Grieshop, A. P., Robinson, A. L., Duplissy, J., Smith, J. D., Wilson, K. R., Lanz, V. A., Hueglin, C., Sun, Y. L., Tian, J., Laaksonen, A., Raatikainen, T., Rautiainen, J., Vaattovaara, P., Ehn, M., Kulmala, M., Tomlinson, J. M., Collins, D. R., Cubison, M. J., E, Dunlea, J., Huffman, J. A., Onasch, T. B., Alfarra, M. R., Williams, P. I., Bower, K., Kondo, Y., Schneider, J., Drewnick, F., Borrmann, S., Weimer, S., Demerjian, K., Salcedo, D., Cot- 
trell, L., Griffin, R., Takami, A., Miyoshi, T., Hatakeyama, S., Shimono, A., Sun, J. Y., Zhang, Y. M., Dzepina, K., Kimmel, J. R., Sueper, D., Jayne, J. T., Herndon, S. C., Trimborn, A. M., Williams, L. R., Wood, E. C., Middlebrook, A. M., Kolb, C. E., Baltensperger, U., and Worsnop, D. R.: Evolution of organic aerosols in the atmosphere, Science, 326, 1525-1529, 2009.

Kalberer, M., Paulsen, D., Sax, M., Steinbacher, M., Dommen, J., Prevot, A., Fisseha, R., Weingartner, E., Frankevich, V., Zenobi, R., and Baltensperger, U.: Identification of Polymers as Major Components of Atmospheric Organic Aerosols, Science, 303, 1659-1662, 2004.

Kerminen, V.-M. and Kulmala, M.: Analytical formulae connecting the "real" and the "apparent" nucleation rate and the nuclei number concentration for atmospheric nucleation events, J. Aerosol Sci., 33, 609-622, 2002.

Kuang, C., Riipinen, I., Sihto, S.-L., Kulmala, M., McCormick, A. V., and McMurry, P. H.: An improved criterion for new particle formation in diverse atmospheric environments, Atmos. Chem. Phys., 10, 8469-8480, doi:10.5194/acp-10-8469-2010, 2010.

Kulmala, M., Vehkamäki, H., Petäjä, T., Dal Maso, M., Lauri, A., Kerminen, V.-M., Birmili, W., and McMurry, P. H.: Formation and growth of ultrafine atmospheric particles: A review of observations, J. Aerosol Sci., 35, 143-176, 2004.

Kulmala, M., Mordas, G., Petäjä, T., Grönholm, T., Aalto, P. P., Vehkamäki, H., Hienola, A. I., Herrmann, E., Sipilä, M., Riipinen, I., Manninen, H., Hämeri, K., Stratmann, F., Bilde, M., Birmili, W., and Wagner, P. E.: The Condensation Particle Counter Battery (CPCB): A New Tool to Investigate the Activation Properties of Nanoparticles, J. Aerosol Sci., 38, 289-304, 2007.

Kulmala, M., Asmi, A., Lappalainen, H. K., Carslaw, K. S., Pöschl, U., Baltensperger, U., Hov, Ø., Brenquier, J.-L., Pandis, S. N., Facchini, M. C., Hansson, H.-C., Wiedensohler, A., and O'Dowd, C. D.: Introduction: European Integrated Project on Aerosol Cloud Climate and Air Quality interactions (EUCAARI) - integrating aerosol research from nano to global scales, Atmos. Chem. Phys., 9, 2825-2841, doi:10.5194/acp-9-2825-2009, 2009.

Merikanto, J., Spracklen, D. V., Mann, G. W., Pickering, S. J., and Carslaw, K. S.: Impact of nucleation on global CCN, Atmos. Chem. Phys., 9, 8601-8616, doi:10.5194/acp-9-8601-2009, 2009.

Metzger, A., Verheggen, B., Dommen, J., Duplissy, J., Prevot, A. S. H., Weingartner, E., Riipinen, I., Kulmala, M., Spracklen, D. V., Carslaw, K. S., and Baltensperger, U.: Evidence for the role of organics in aerosol particle formation under atmospheric conditions, Proc. Natl. Acad. Sci., 107, 6646-6651, doi:10.1073/pnas.0911330107, 2010.

Mirme, A., Tamm, E., Mordas, G., Vana, M., Uin, J., Mirme, S., Bernotas, T., Laakso, L., Hirsikko, A., and Kulmala, M.: A widerange multi-channel Air Ion Specrometer, Boreal Environ. Res., 12, 247-264, 2007.

Murphy, B. N. and Pandis, S.N.: Simulating the Formation of Semivolatile Primary and Secondary Organic Aerosol in a Regional Chemical Transport Model, Environ. Sci. Technol., 43, 4722-4728, doi:10.1021/es803168a, 2009.

Nel, A.: Air Pollution-Related Illness: Effects of Particles, Science, 308, 804-806, 2005.

Nieminen, T., Lehtinen, K. E. J., and Kulmala, M.: Sub-10 nm particle growth by vapor condensation - effects of vapor molecule size and particle thermal speed, Atmos. Chem. Phys., 10, 9773 9779, doi:10.5194/acp-10-9773-2010, 2010.

O’Dowd, C. D., Aalto, P., Hämeri, K., Kulmala, M., and Hoffmann, T.: Atmospheric particles from organic vapors, Nature, 416, 497-498, 2002.

Odum, J. R., Hoffmann, T., Bowman, F., Collins, D., Flagan, R. C., and Seinfeld, J. H.: Gas/particle partitioning and secondary organic aerosol yields, Environ. Sci. Technol., 30, 2580-2585, 1996.

Pankow, J. F.: An Absorption Model of Gas/Particle Partitioning of Organic Compounds in the Atmosphere, Atmos. Environ., 28, 185-188, 1994.

Petäjä, T., Mauldin, III, R. L., Kosciuch, E., McGrath, J., Nieminen, T., Paasonen, P., Boy, M., Adamov, A., Kotiaho, T., and Kulmala, M.: Sulfuric acid and $\mathrm{OH}$ concentrations in a boreal forest site, Atmos. Chem. Phys., 9, 7435-7448, doi:10.5194/acp9-7435-2009, 2009.

Pierce, J. R. and Adams, P. J.: Uncertainty in global CCN concentrations from uncertain aerosol nucleation and primary emission rates, Atmos. Chem. Phys., 9, 1339-1356, doi:10.5194/acp-91339-2009, 2009.

Riipinen, I., Manninen, H. E., Yli-Juuti, T., Boy, M., Sipilä, M., Ehn, M., Junninen, H., Petäjä, T., and Kulmala, M.: Applying the Condensation Particle Counter Battery (CPCB) to study the water-affinity of freshly-formed $2-9 \mathrm{~nm}$ particles in boreal forest, Atmos. Chem. Phys., 9, 3317-3330, doi:10.5194/acp-93317-2009, 2009.

Robinson, A. L., Donahue, N. M., Shrivastava, M. K., Weitkamp, E. A., Sage, A. M., Grieshop, A. P., Lane, T. E., Pierce, J. R., and Pandis, S. N.: Rethinking Organic Aerosols: Semivolatile Emissions and Photochemical Aging, Science, 315, 1259-1262, 2007.

Rosenfeld, D., Lohmann, U., Raga, G. B., O’Dowd, C. D., Kulmala, M., Fuzzi, S., Reissell, A., and Andreae, M. O.: Flood or Drought: How Do Aerosols Affect Precipitation?, Science, 312, 1309-1313, 2008.

Seinfeld, J. H. and Pandis, S. N.: Atmospheric Chemistry and Physics, 2nd Edn., John Wiley and Sons, New York, 2006.

Sihto, S.-L., Kulmala, M., Kerminen, V.-M., Dal Maso, M., Petäjä, T., Riipinen, I., Korhonen, H., Arnold, F., Janson, R., Boy, M., Laaksonen, A., and Lehtinen, K. E. J.: Atmospheric sulphuric acid and aerosol formation: implications from atmospheric measurements for nucleation and early growth mechanisms, Atmos. Chem. Phys., 6, 4079-4091, doi:10.5194/acp-6-4079-2006, 2006.

Sipilä, M., Berndt, T., Petäjä, T., Brus, D., Vanhanen, J., Stratmann, F., Patokoski, J., Mauldin III, R. L., Hyvärinen, A.-P., Lihavainen, H., and Kulmala, M.: Role of Sulfuric Acid in Atmospheric Nucleation, Science, 327, 1243-1246, 2010.

Slowik, J. G., Stroud, C., Bottenheim, J. W., Brickell, P. C., Chang, R. Y.-W., Liggio, J., Makar, P. A., Martin, R. V., Moran, M. D., Shantz, N. C., Sjostedt, S. J., van Donkelaar, A., Vlasenko, A., Wiebe, H. A., Xia, A. G., Zhang, J., Leaitch, W. R., and Abbatt, J. P. D.: Characterization of a large biogenic secondary organic aerosol event from eastern Canadian forests, Atmos. Chem. Phys., 10, 2825-2845, doi:10.5194/acp-10-2825-2010, 2010.

Spracklen, D. V., Carslaw, K. S., Merikanto, J., Mann, G. W., Reddington, C. L., Pickering, S., Ogren, J. A., Andrews, E., Baltensperger, U., Weingartner, E., Boy, M., Kulmala, M., Laakso, 
L., Lihavainen, H., Kivekäs, N., Komppula, M., Mihalopoulos, N., Kouvarakis, G., Jennings, S. G., O’Dowd, C., Birmili, W., Wiedensohler, A., Weller, R., Gras, J., Laj, P., Sellegri, K., Bonn, B., Krejci, R., Laaksonen, A., Hamed, A., Minikin, A., Harrison, R. M., Talbot, R., and Sun, J.: Explaining global surface aerosol number concentrations in terms of primary emissions and particle formation, Atmos. Chem. Phys., 10, 4775-4793, doi:10.5194/acp-10-4775-2010, 2010.

Tammet, H.: Continuous scanning of the mobility and size distribution of charged clusters and nanometer particles in atmospheric air and the Balanced Scanning Mobility Analyzer BSMA, Atmos. Res., 82, 523-535, 2006.

Trivitayanurak, W., Adams, P. J., Spracklen, D. V., and Carslaw, K. S.: Tropospheric aerosol microphysics simulation with assimilated meteorology: model description and intermodel comparison, Atmos. Chem. Phys., 8, 3149-3168, doi:10.5194/acp-83149-2008, 2008.
Vehkamäki, H., Kulmala, M., Napari, I., Lehtinen, K. E. J., Timmreck, C., Noppel, M., and Laaksonen, A.: An improved parameterization for sulfuric acid-water nucleation rates for tropospheric and stratospheric conditions, J. Geophys. Res., 107(D22), 46224631, doi:10.1029/2002JD002184, 2002.

Vesala, T., Kulmala, M., Rudolf, R., Vrtala, A., and Wagner, P. E.: Models for condensational growth and evaporation of binary aerosol particles, J. Aerosol Sci., 28, 565-598, 1997.

Virtanen, A., Joutsensaari, J., Koop, T., Kannosto, J., Yli-Pirilä, P., Leskinen, J., Mäkelä, J. M., Holopainen, J. K., Pöschl, U., Kulmala, M., Worsnop, D. R., and Laaksonen, A.: An amorphous solid state of biogenic secondary organic aerosol, Nature, 467, 824-827, 2010.

Yu, F.: A secondary organic aerosol formation model considering successive oxidation aging and kinetic condensation of organic compounds: global scale implications, Atmos. Chem. Phys., 11, 1083-1099, doi:10.5194/acp-11-1083-2011, 2011. 